Article

\title{
A Novel "Off-On" Fluorescent Probe Based on Carbon Nitride Nanoribbons for the Detection of Citrate Anion and Live Cell Imaging
}

\author{
Yanling Hu ${ }^{1}$, Dongliang Yang ${ }^{1}$, Chen Yang ${ }^{1}$, Ning Feng ${ }^{1}$, Zhouwei Shao ${ }^{1}$, Lei Zhang ${ }^{1}$ (D), \\ Xiaodong Wang ${ }^{1}$, Lixing Weng ${ }^{2}$, Zhimin Luo ${ }^{1}$ and Lianhui Wang ${ }^{1, *}$ \\ 1 Key Laboratory for Organic Electronics \& Information Displays (KLOEID) and Jiangsu Key Laboratory for \\ Biosensors, Institute of Advanced Materials (IAM), Nanjing University of Posts and Telecommunications, \\ 9 Wenyuan Road, Nanjing 210023, China; huyanling124@hotmail.com (Y.H.); yangdl1023@163.com (D.Y.); \\ 1015061531@njupt.edu.cn (C.Y.); 18705196782@163.com (N.F.); 18305167897@163.com (Z.S.); \\ iamlzhang@njupt.edu.cn (L.Z.); 18851825985@163.com (X.W.); iamzmluo@njupt.edu.cn (Z.L.) \\ 2 College of Geography and Biological Information, Nanjing University of Posts and Telecommunications, \\ 9 Wenyuan Road, Nanjing 210023, China; lxweng@njupt.edu.cn \\ * Correspondence: iamlhwang@njupt.edu.cn; Tel.: +86-25-8586-6332
}

Received: 9 March 2018; Accepted: 6 April 2018; Published: 11 April 2018

check for updates

\begin{abstract}
A novel fluorescent "off-on" probe based on carbon nitride $\left(\mathrm{C}_{3} \mathrm{~N}_{4}\right)$ nanoribbons was developed for citrate anion $\left(\mathrm{C}_{6} \mathrm{H}_{5} \mathrm{O}_{7}{ }^{3-}\right)$ detection. The fluorescence of $\mathrm{C}_{3} \mathrm{~N}_{4}$ nanoribbons can be quenched by $\mathrm{Cu}^{2+}$ and then recovered by the addition of $\mathrm{C}_{6} \mathrm{H}_{5} \mathrm{O}_{7}{ }^{3-}$, because the chelation between $\mathrm{C}_{6} \mathrm{H}_{5} \mathrm{O}_{7}{ }^{3-}$ and $\mathrm{Cu}^{2+}$ blocks the electron transfer between $\mathrm{Cu}^{2+}$ and $\mathrm{C}_{3} \mathrm{~N}_{4}$ nanoribbons. The turn-on fluorescent sensor using this fluorescent "off-on" probe can detect $\mathrm{C}_{6} \mathrm{H}_{5} \mathrm{O}_{7}{ }^{3-}$ rapidly and selectively, showing a wide detection linear range $(1 \sim 400 \mu \mathrm{M})$ and a low detection limit $(0.78 \mu \mathrm{M})$ in aqueous solutions. Importantly, this $\mathrm{C}_{3} \mathrm{~N}_{4}$ nanoribbon-based "off-on" probe exhibits good biocompatibility and can be used as fluorescent visualizer for exogenous $\mathrm{C}_{6} \mathrm{H}_{5} \mathrm{O}_{7}{ }^{3-}$ in HeLa cells.
\end{abstract}

Keywords: carbon nitride; nanoribbons; fluorescent detection; citrate anion; biosensing

\section{Introduction}

Citrate is a critical metabolite that is involved in various biological systems, such as mitochondrial energy generation, cytosolic biomacromolecular synthesis, inflammatory response, blood coagulation, and the regulation of the size of apatite crystals in bone [1-5]. Citrate deficiency is the main reason for kidney dysfunction such as nephrocalcinosis and nephrolithiasis [6]. Recent medical research has shown that the tracking of citrate levels has become an effective method for the identification of prostate cancer [2,7]. Therefore, monitoring citrate content is of great importance in biomedical and analytical sciences. To date, many analytical methods have been used for citrate detection including electrochemistry [8], capillary electrophoresis [9], polarography [10], gas or liquid chromatography [11,12], UV-vis spectrophotometry [6,13], and spectrofluorimetry [14,15]. The spectrofluorimetry method has attracted great attention owing to its easy operation, high sensitivity, and lower equipment requirements $[6,13,16]$.

Carbon nitride $\left(\mathrm{C}_{3} \mathrm{~N}_{4}\right)$ is a metal-free polymeric semi-conductor with a narrow bandgap of about $2.7 \mathrm{eV}$. Due to its special photoluminescence (PL), facile synthesis, and good biocompatibility $[17,18]$, $\mathrm{C}_{3} \mathrm{~N}_{4}$ has been applied for environmental decontamination, artificial photosynthesis, biotherapy, bioimaging, and sensors [17-24]. So far, some fluorescent sensing platforms based on $\mathrm{C}_{3} \mathrm{~N}_{4}$ have been designed for the detection of various ions and molecules, including $\mathrm{Cu}^{2+}, \mathrm{Fe}^{3+}, \mathrm{Ag}^{+}$, acetylthiocholine, 
biothiols, and cyanide $[18,23,25,26]$. However, to the best of our knowledge, there is no report of fluorescent sensors based on $\mathrm{C}_{3} \mathrm{~N}_{4}$ nanoribbons for citrate anion detection.

In this work, blue fluorescent $\mathrm{C}_{3} \mathrm{~N}_{4}$ nanoribbons were prepared by alkali-catalyzed hydrolysis from bulk $\mathrm{C}_{3} \mathrm{~N}_{4}$ [27]. Furthermore, we demonstrated that the obtained $\mathrm{C}_{3} \mathrm{~N}_{4}$ nanoribbons can serve as a novel "off-on" fluorescent probe for the detection of citrate anion $\left(\mathrm{C}_{6} \mathrm{H}_{5} \mathrm{O}_{7}{ }^{3-}\right)$ with excellent sensitivity and selectivity based on fluorescence quenching by $\mathrm{Cu}^{2+}$ through a photoinduced electron transfer $[28,29]$ and fluorescence recovery by the addition of $\mathrm{C}_{6} \mathrm{H}_{5} \mathrm{O}_{7}{ }^{3-}$. We hypothesized that the interaction of $\mathrm{Cu}^{2+}$ and $\mathrm{C}_{3} \mathrm{~N}_{4}$ nanoribbons is inhibited by the strong chelation between $\mathrm{Cu}^{2+}$ and $\mathrm{C}_{6} \mathrm{H}_{5} \mathrm{O}_{7}{ }^{3-}$ [30-32]. This is the first time that $\mathrm{C}_{3} \mathrm{~N}_{4}$ nanoribbons have been applied for $\mathrm{C}_{6} \mathrm{H}_{5} \mathrm{O}_{7}{ }^{3-}$ detection. Importantly, the turn-on fluorescent sensor using this fluorescent "off-on" probe exhibits low cytotoxicity and can be applied for $\mathrm{C}_{6} \mathrm{H}_{5} \mathrm{O}_{7}{ }^{3-}$ detection in living cells. Scheme 1 illustrates the sensing principle of the $\mathrm{C}_{3} \mathrm{~N}_{4}$ nanoribbon-based fluorescent sensor.

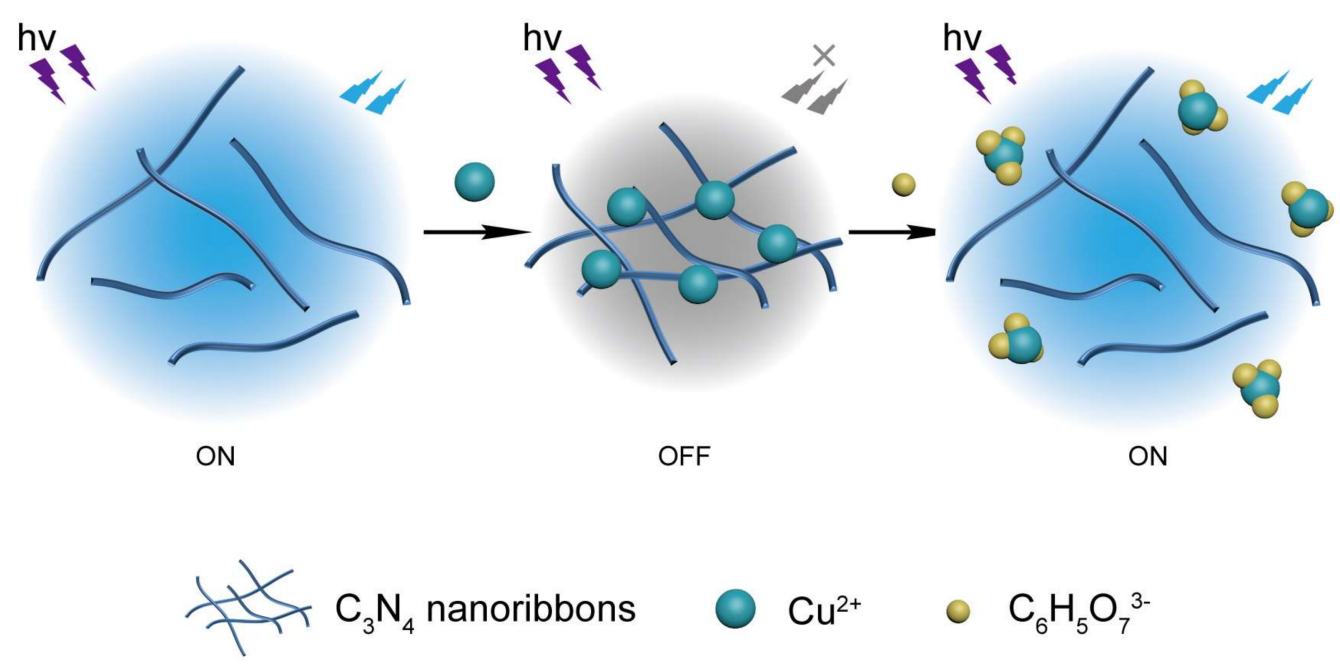

Scheme 1. Schematic illustration of the $\mathrm{C}_{3} \mathrm{~N}_{4}$ nanoribbon-based fluorescent citrate sensor.

\section{Materials and Methods}

\subsection{Materials and Reagents}

Dulbecco's modified Eagle's medium (DMEM), fetal bovine serum, and 3-(4,5-dimethyl-thiazol2-yl)-2,5-diphenyltetrazolium bromide (MTT) were purchased from Hyclone. HeLa cells were supplied by KeyGen Biotech Co., Ltd. (Nanjing, China). All inorganic salts were of analytical grade and obtained from Aladdin reagent (Shanghai, China). Formic acid, sodium acetate, and propionic acid were purchased from Sinopharm Chemical Reagent Co., Ltd. (Beijing, China). Ultrapure water (Milli-Q system, Millipore Corp., Billerica, MA, USA) was used throughout this study.

\subsection{Characterization}

UV-vis spectroscopy measurements were performed on a Shimadzu UV-3600 spectrophotometer. Fluorescence spectra were recorded on an RF-5301PC spectrofluorophotometer. The Fourier transform infrared (FTIR) spectrum of $\mathrm{C}_{3} \mathrm{~N}_{4}$ nanoribbons was measured on a Nexus 870 FTIR spectrometer. A JEOL 2010 transmission electron microscope (TEM) was used for the characterization of $C_{3} N_{4}$ nanoribbons. The X-ray diffraction (XRD) pattern of $\mathrm{C}_{3} \mathrm{~N}_{4}$ nanoribbons was recorded on an X-ray powder diffractometer with graphite monochromatized $\mathrm{Cu} \mathrm{K} \alpha$ radiation (D8 Advance; Bruker, Karlsruhe, Germany). The X-ray photoelectron spectroscopy (XPS) investigation was carried out on PHI 5000 VersaProbe system with $\mathrm{Al}$ cathode as the $\mathrm{X}$-ray source. The $\mathrm{C}_{3} \mathrm{~N}_{4}$ nanoribbons was dropped on silicon slices for XPS characterization. Dynamic light scattering (DLS) and zeta potential measurements were conducted on a zeta potential analyzer (Zeta PALS, Brookhaven Instruments Corp., 
Brookhaven, NY, USA). Cell fluorescent images were recorded by confocal laser scanning microscopy (Olympus FV1000, Tokyo, Japan).

\subsection{Preparation of $\mathrm{C}_{3} \mathrm{~N}_{4}$ Nanoribbons}

The bulk $\mathrm{C}_{3} \mathrm{~N}_{4}$ was prepared by the calcination of melamine at $600{ }^{\circ} \mathrm{C}\left(5.0^{\circ} \mathrm{C} \mathrm{min}-1\right)$ for $4 \mathrm{~h}$ under an $\mathrm{Ar}$ atmosphere [33]. The $\mathrm{C}_{3} \mathrm{~N}_{4}$ nanoribbons were prepared via the alkali-catalyzed hydrolysis of bulk $\mathrm{C}_{3} \mathrm{~N}_{4}$ [27]. In brief, $10 \mathrm{mg}$ of bulk $\mathrm{C}_{3} \mathrm{~N}_{4}$ was dispersed in $10 \mathrm{~mL}$ of sodium hydroxide solution $(8.0 \mathrm{M})$ and sonicated for $2 \mathrm{~h}$ at $60^{\circ} \mathrm{C}$. After cooling to room temperature, this solution was centrifuged and washed five times with ultrapure water. The product was collected and dialyzed (the molecular weight cutoff of the dialysis bag was $1000 \mathrm{kDa}$ ) for further experiments.

\subsection{Synthesis of $\mathrm{Cu}^{2+}-C_{3} \mathrm{~N}_{4}$ Nanoribbon Complex}

One hundred microliters of $\mathrm{CuCl}_{2}(10 \mathrm{mM})$ was added to $9.9 \mathrm{~mL}$ of $\mathrm{C}_{3} \mathrm{~N}_{4}$ nanoribbons aqueous solution $\left(1 \mathrm{mg} \mathrm{mL}^{-1}\right)$. Then, the mixture was stirred for $10 \mathrm{~min}$ at room temperature. After that, the mixture was centrifuged and washed with ultrapure water to remove excessive copper ions. Finally, the obtained precipitate was dispersed in ultrapure water to obtain a $\mathrm{Cu}^{2+}-\mathrm{C}_{3} \mathrm{~N}_{4}$ nanoribbon solution.

\subsection{Fluorescent Detection of $\mathrm{C}_{6} \mathrm{H}_{5} \mathrm{O}_{7}{ }^{3-}$}

Forty microliters of $\mathrm{Cu}^{2+}-\mathrm{C}_{3} \mathrm{~N}_{4}$ nanoribbon complex $\left(\mathrm{C}_{3} \mathrm{~N}_{4}: 1 \mathrm{mg} \mathrm{mL}^{-1}\right)$ was added to $960 \mu \mathrm{L}$ ultrapure water, and then $\mathrm{C}_{6} \mathrm{H}_{5} \mathrm{O}_{7}^{3-}$ solution with various concentrations was added to the $\mathrm{Cu}^{2+}-\mathrm{C}_{3} \mathrm{~N}_{4}$ nanoribbon complex. After standing for $20 \mathrm{~s}$, the fluorescence spectra were monitored at the excitation of $360 \mathrm{~nm}$.

\subsection{Selectivity of $\mathrm{Cu}^{2+}-\mathrm{C}_{3} \mathrm{~N}_{4}$ Nanoribbon-Based Probe for $\mathrm{C}_{6} \mathrm{H}_{5} \mathrm{O}_{7}{ }^{3-}$ Detection}

To explore the possible interference of other anions, formic acid, sodium acetate, propionic acid and the following anionic sodium/potassium salts were used in this study: $1 \mathrm{mM}$ anion solutions, including $\mathrm{Br}^{-}, \mathrm{C}_{6} \mathrm{H}_{5} \mathrm{O}_{7}{ }^{3-}, \mathrm{Cl}^{-}, \mathrm{CN}^{-}, \mathrm{F}^{-}, \mathrm{H}_{2} \mathrm{PO}_{4}{ }^{-}, \mathrm{HCO}_{3}{ }^{-}, \mathrm{I}^{-}, \mathrm{NO}_{3}{ }^{-}, \mathrm{OH}^{-}, \mathrm{CH}_{3} \mathrm{COO}^{-}$, and $\mathrm{SO}_{4}{ }^{2-}$ were added to the solution of the $\mathrm{Cu}^{2+}-\mathrm{C}_{3} \mathrm{~N}_{4}$ nanoribbon complex, respectively. After thoroughly mixing and standing for $20 \mathrm{~s}$, the fluorescence measurements were carried out to investigate the selectivity of the proposed fluorescent sensor.

\subsection{Cell Imaging and Cytotoxicity Assay}

Human cervical cancer (HeLa) cells used in this study were cultured at $37{ }^{\circ} \mathrm{C}$ in a $5 \% \mathrm{CO}_{2}$ incubator in DMEM medium, which contains fetal bovine serum $(10 \%)$, streptomycin $\left(100 \mathrm{mg} \mathrm{mL}^{-1}\right)$, and penicillin $\left(100 \mathrm{U} \mathrm{mL}^{-1}\right)$. When the cells had grown to $80 \%$ confluency, the cells were digested with trypsin, collected and seeded in a confocal dish, and cultured overnight. Then the cells were pretreated with $\mathrm{C}_{6} \mathrm{H}_{5} \mathrm{O}_{7} \mathrm{Na}_{3}(1 \mathrm{mM})$. After $12 \mathrm{~h}$ incubation, the cells were gently washed with phosphate-buffered saline (PBS) solution $(10 \mathrm{mM}, \mathrm{pH}=7.4)$ and treated with $\mathrm{Cu}^{2+}-\mathrm{C}_{3} \mathrm{~N}_{4}$ nanoribbon complex for another $4 \mathrm{~h}$. Finally, the resulting cells were washed with PBS solution $(10 \mathrm{mM}, \mathrm{pH}=7.4)$ and then fluorescence images were taken on a confocal microscope under UV excitation.

For cytotoxicity assay, $100 \mu \mathrm{L}$ of cells suspension $\left(10^{5}\right.$ cells $\left.\mathrm{mL}^{-1}\right)$ was seeded to each well of 96-well plates. Then the medium was replaced by different concentrations of $\mathrm{C}_{3} \mathrm{~N}_{4}$ nanoribbons or $\mathrm{Cu}^{2+}{ }_{-} \mathrm{C}_{3} \mathrm{~N}_{4}$ nanoribbon complex and culture for $24 \mathrm{~h}$. Following this, the cells were washed with PBS solution. After that, the standard MTT assay was carried out for the determination of cell viabilities relative to the untreated cells. 


\section{Results and Discussion}

\subsection{Characterization of $\mathrm{C}_{3} \mathrm{~N}_{4}$ Nanoribbons}

The $\mathrm{C}_{3} \mathrm{~N}_{4}$ nanoribbons were prepared by ultrasonic exfoliation of bulk $\mathrm{C}_{3} \mathrm{~N}_{4}$ in an alkaline solution. The related characterizations of bulk $\mathrm{C}_{3} \mathrm{~N}_{4}$ are shown in Figure S1. TEM images display the morphology and size distribution of the $\mathrm{C}_{3} \mathrm{~N}_{4}$ nanoribbons. As shown Figure $1 \mathrm{a}, \mathrm{C}_{3} \mathrm{~N}_{4}$ nanoribbons present an average diameter of approximately $5 \mathrm{~nm}$ and a length of up to $200 \mathrm{~nm}$. High-resolution transmission electron microscopy (HRTEM) image clearly shows that single and few-layer $\mathrm{C}_{3} \mathrm{~N}_{4}$ nanoribbons were obtained (Figure $1 b$ ). The XRD pattern of $C_{3} N_{4}$ nanoribbons (Figure 1c) showed a broad distinct diffraction peak at $27.2^{\circ}$, which can be ascribed to the strong $\pi$-conjugated layers characteristic (002) of $\mathrm{C}_{3} \mathrm{~N}_{4}[17,34]$.
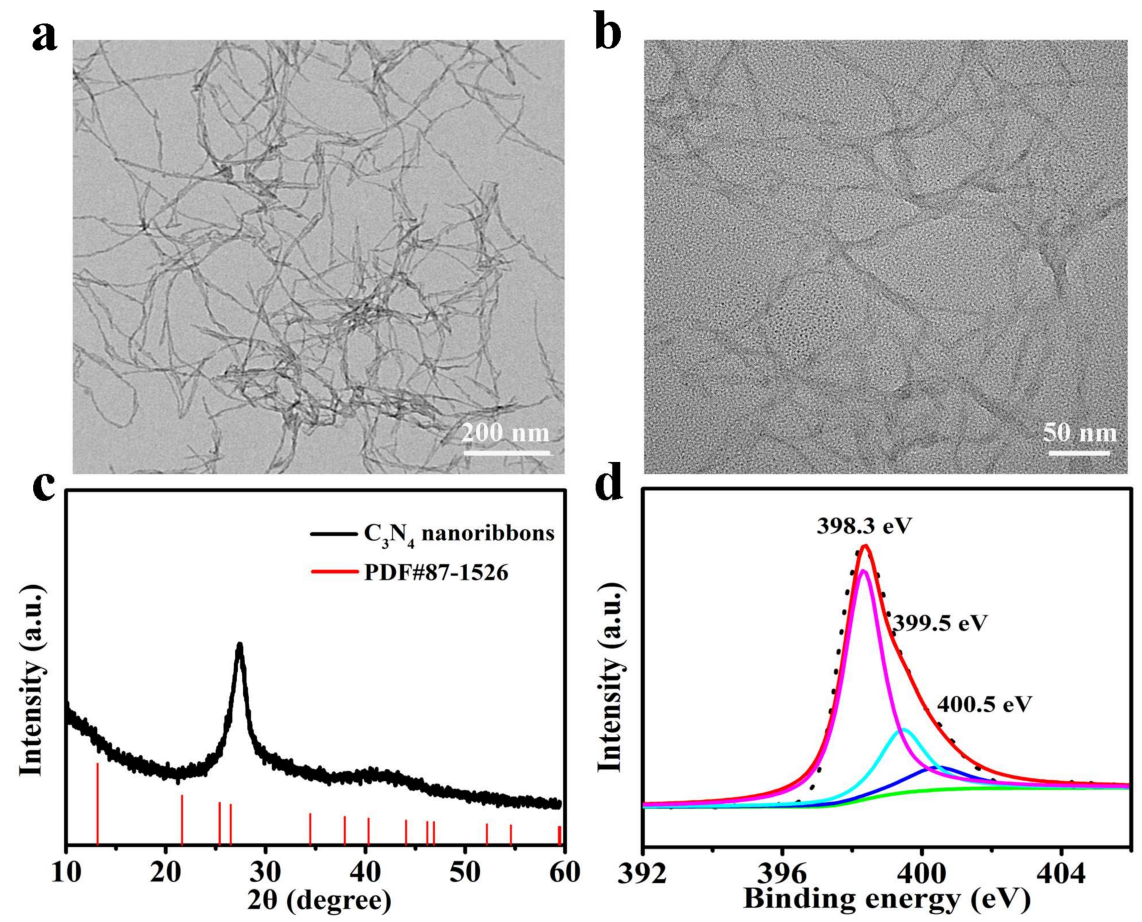

Figure 1. (a) TEM image, (b) HRTEM image, (c) X-ray diffraction (XRD) pattern and (d) N 1s X-ray photoelectron spectroscopy (XPS) spectrum of $\mathrm{C}_{3} \mathrm{~N}_{4}$ nanoribbons.

The composition and structure of $\mathrm{C}_{3} \mathrm{~N}_{4}$ nanoribbons were confirmed by XPS and FTIR measurements. The XPS survey spectrum of $\mathrm{C}_{3} \mathrm{~N}_{4}$ nanoribbons (Figure S2) displays binding energies of $\mathrm{C}(283 \mathrm{eV}$ ) and $\mathrm{N}(397 \mathrm{eV})$. The $\mathrm{C}$ 1s XPS spectrum of $\mathrm{C}_{3} \mathrm{~N}_{4}$ nanoribbons (Figure S3) can be fitted into three peaks centering at 284.6, 285.4, and $287.8 \mathrm{eV}$, which can be attributed to $\mathrm{C}-\mathrm{C}, \mathrm{sp}^{2} \mathrm{C}=\mathrm{N}$, and sp $\mathrm{s}^{3} \mathrm{C}-\mathrm{N}$ of $\mathrm{C}_{3} \mathrm{~N}_{4}$, respectively [35-39]. The XPS spectrum of the $\mathrm{N} 1 \mathrm{~s}$ spectrum (Figure 1d) can be fitted into three different peaks at 398.3, 399.5, and $400.5 \mathrm{eV}$, being assigned to $\mathrm{C}=\mathrm{N}-\mathrm{C},\left(\mathrm{N}-(\mathrm{C})_{3}\right)$, and $-\mathrm{NH}_{2}$, respectively $[36,40]$. The FTIR spectrum of $\mathrm{C}_{3} \mathrm{~N}_{4}$ nanoribbons is presented in Figure $S 4$. The broad peaks at 3330 and $3182 \mathrm{~cm}^{-1}$ are ascribed to the stretching vibrations of $\mathrm{NH}_{2}$ and $\mathrm{N}-\mathrm{H}$ groups, respectively [39]. The peaks centered at $1637,1577,1420,1334$, and $1284 \mathrm{~cm}^{-1}$ indicated the typical stretching modes of CN heterocycles [41-43]. Beside the peaks mentioned above, the peak at $810 \mathrm{~cm}^{-1}$ indicated the vibration of the s-triazine ring [34,44].

The photophysical properties of $\mathrm{C}_{3} \mathrm{~N}_{4}$ nanoribbons were investigated by UV-vis and PL spectra (Figure 2a). The prepared $\mathrm{C}_{3} \mathrm{~N}_{4}$ nanoribbons present two strong absorption peaks at 216 and $278 \mathrm{~nm}$. Meanwhile, a fluorescent emission at $415 \mathrm{~nm}$ can be seen from fluorescence spectrum at the excitation of $360 \mathrm{~nm}$ (Figure 2a). The PL intensity of $\mathrm{C}_{3} \mathrm{~N}_{4}$ nanoribbons increases dramatically with the increasing $\mathrm{pH}$ of solution ranging from 9 to 12, and displays slight changes under acid conditions (Figure S5). 

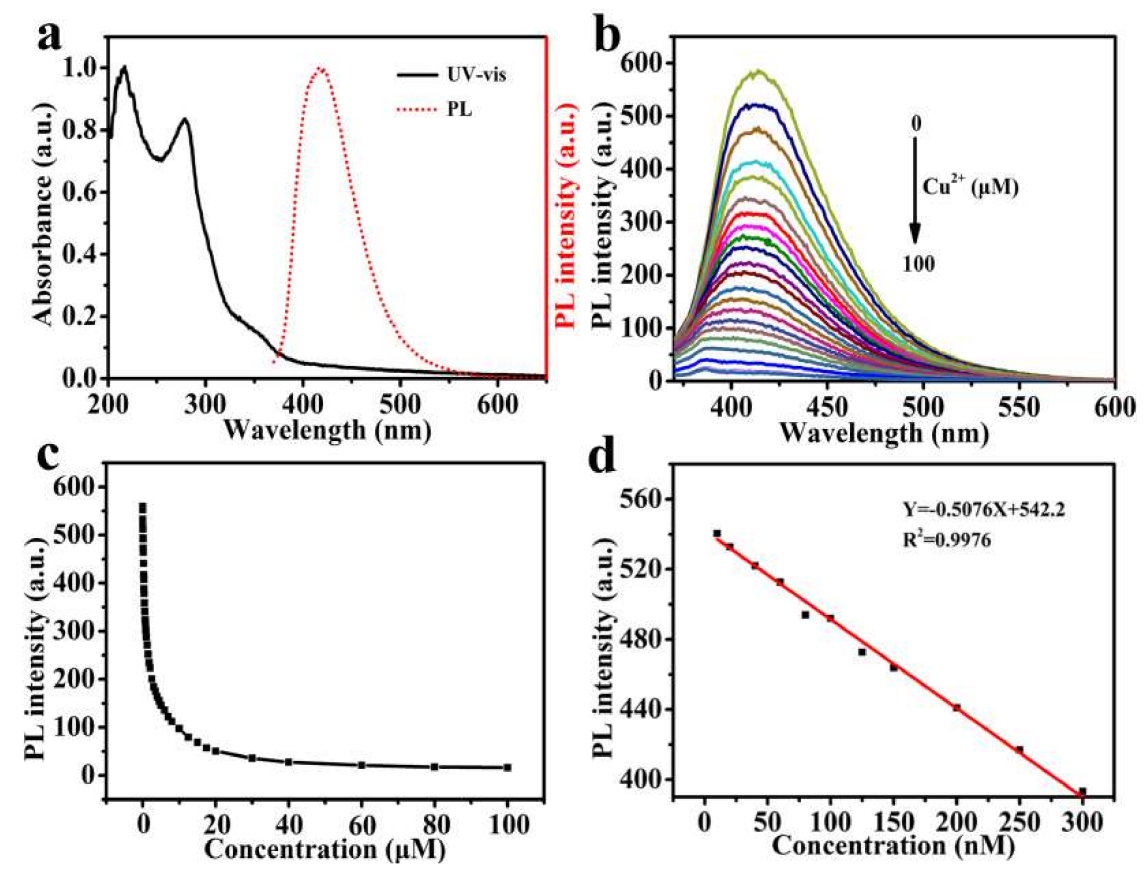

Figure 2. (a) UV-vis and photoluminescence (PL) spectra of $C_{3} N_{4}$ nanoribbons. (b) The PL spectra of $C_{3} N_{4}$ nanoribbons $\left(40 \mu \mathrm{g} \mathrm{mL}^{-1}\right)$ in the presence of different concentrations of $\mathrm{Cu}^{2+}$. (c) PL intensity responses of $\mathrm{C}_{3} \mathrm{~N}_{4}$ nanoribbons with varying concentrations of $\mathrm{Cu}^{2+}$ in an aqueous solution. (d) The linear calibration of PL intensity versus the concentrations of $\mathrm{Cu}^{2+}$.

\subsection{The Influence of Metal Ions on the Fluorescence of $C_{3} N_{4}$ Nanoribbons}

A previous study indicated that $\mathrm{Cu}^{2+}, \mathrm{Fe}^{3+}$, and $\mathrm{Ag}^{+}$can quench the fluorescence of $\mathrm{C}_{3} \mathrm{~N}_{4}$ due to the photoinduced electron transfer from $C_{3} N_{4}$ to metal ions $[23,25,45]$. In this experiment, the fluorescent responses of $\mathrm{C}_{3} \mathrm{~N}_{4}$ nanoribbons towards different metal ions were investigated. As shown in Figure $\mathrm{S} 6$, $\mathrm{C}_{3} \mathrm{~N}_{4}$ nanoribbons display a slight change of the PL intensity in the presence of $\mathrm{Al}^{3+}, \mathrm{Ba}^{2+}, \mathrm{K}^{+}, \mathrm{Li}^{+}, \mathrm{Mg}^{2+}$, $\mathrm{Na}^{+}, \mathrm{Pb}^{2+}, \mathrm{Sn}^{2+}$, and $\mathrm{Zn}^{2+}(100 \mu \mathrm{M})$. However, the PL intensity of $\mathrm{C}_{3} \mathrm{~N}_{4}$ nanoribbons dramatically decreases with the addition of $\mathrm{Cu}^{2+}, \mathrm{Ag}^{+}, \mathrm{Fe}^{3+}, \mathrm{Co}^{2+}, \mathrm{Mn}^{2+}$, and $\mathrm{Ni}^{2+}$, especially for $\mathrm{Cu}^{2+}$ and $\mathrm{Ag}^{+} . \mathrm{Cu}^{2+}$ was chosen as the quencher in this work [36]. A decrease of PL intensity of $\mathrm{C}_{3} \mathrm{~N}_{4}$ nanoribbons is observed as the concentration of $\mathrm{Cu}^{2+}$ increases (Figure $2 \mathrm{~b}, \mathrm{c}$ ), and it is almost completely quenched after the addition of $40 \mu \mathrm{M} \mathrm{Cu}^{2+}$. Figure $2 \mathrm{~d}$ shows that the PL intensity of $\mathrm{C}_{3} \mathrm{~N}_{4}$ at $415 \mathrm{~nm}$ versus the concentrations of $\mathrm{Cu}^{2+}$ exhibits a linear relationship ranging from 10 to $300 \mathrm{nM}\left(R^{2}=0.9976\right)$.

\subsection{Sensitivity and Selectivity of the Fluorescent "Off-On" Probe Based on $\mathrm{C}_{3} \mathrm{~N}_{4}$ Nanoribbons for $\mathrm{C}_{6} \mathrm{H}_{5} \mathrm{O}_{7}^{3-}$ Detection}

The influence of incubation time on the fluorescence recovery of $C_{3} N_{4}$ nanoribbons was measured. As Figure S7 displayed, the PL intensity of $\mathrm{Cu}^{2+}-\mathrm{C}_{3} \mathrm{~N}_{4}$ nanoribbon complex increases rapidly with the time after the addition of $\mathrm{C}_{6} \mathrm{H}_{5} \mathrm{O}_{7}{ }^{3-}$, and maintains a plateau after $20 \mathrm{~s}$. Therefore, an incubation time of $20 \mathrm{~s}$ was selected for subsequent experiments.

As is well known, sensitivity is a critical parameter to assess the sensing performance [46,47]. The sensitivity of the fluorescent sensor using the $\mathrm{C}_{3} \mathrm{~N}_{4}$ nanoribbon-based "off-on" probe was evaluated. The PL intensity of the $\mathrm{Cu}^{2+}{ }_{-} \mathrm{C}_{3} \mathrm{~N}_{4}$ nanoribbon complex with different concentrations of $\mathrm{C}_{6} \mathrm{H}_{5} \mathrm{O}_{7}{ }^{3-}$ was recorded. As illustrated in Figure $3 a, b$, the PL intensity of the $\mathrm{Cu}^{2+}-\mathrm{C}_{3} \mathrm{~N}_{4}$ nanoribbon complex was obviously recovered as the concentration of $\mathrm{C}_{6} \mathrm{H}_{5} \mathrm{O}_{7}{ }^{3-}$ increased. The PL intensity of the $\mathrm{Cu}^{2+}-\mathrm{C}_{3} \mathrm{~N}_{4}$ nanoribbon complex was completely recovered with the addition of $\mathrm{C}_{6} \mathrm{H}_{5} \mathrm{O}_{7}{ }^{3-}(2.25 \mathrm{mM})$. The fluorescent sensor using the $\mathrm{C}_{3} \mathrm{~N}_{4}$ nanoribbon-based "off-on" probe shows a linear range from 1 to $400 \mu \mathrm{M}$ and the calculated detection limit is $0.78 \mu \mathrm{M}(\mathrm{S} / \mathrm{N}=3)$ (inset in Figure $3 b)$. Compared with previously reported 
fluorescent probes, such as coumarin [6], rhodamine [13], diketoprrrolopyrrole [15], TPIOP-boronate [48], and CdTe quantum dots [14], the fluorescent sensor using the $\mathrm{C}_{3} \mathrm{~N}_{4}$ nanoribbon-based "off-on" probe exhibits better sensing performance for $\mathrm{C}_{6} \mathrm{H}_{5} \mathrm{O}_{7}{ }^{3-}$ detection with a broader linear range and faster response time (Table S1) $[6,14,15,49]$.
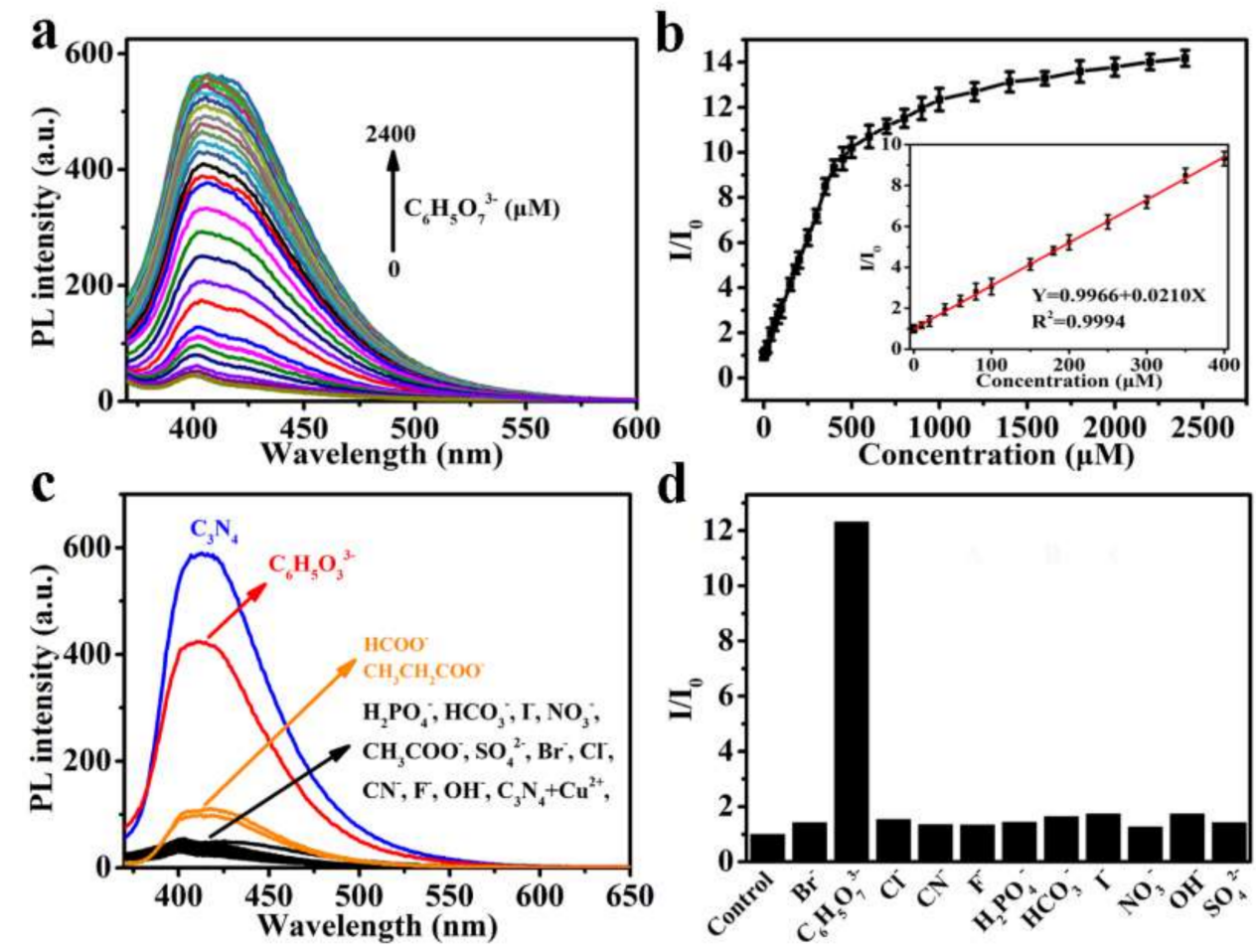

Figure 3. (a) Fluorescence spectra of $\mathrm{Cu}^{2+}{ }_{-} \mathrm{C}_{3} \mathrm{~N}_{4}$ nanoribbon complex with increasing concentrations of $\mathrm{C}_{6} \mathrm{H}_{5} \mathrm{O}_{7}{ }^{3-}$. (b) Plot of the fluorescence enhancement $\left(\mathrm{I} / \mathrm{I}_{0}\right)$ of the $\mathrm{Cu}^{2+}-\mathrm{C}_{3} \mathrm{~N}_{4}$ nanoribbon complex after the addition of different concentrations of $\mathrm{C}_{6} \mathrm{H}_{5} \mathrm{O}_{7}{ }^{3-}$. The linear calibration range from 1 to $400 \mu \mathrm{M}$ is shown as an inset. (c) Fluorescence spectra of the $\mathrm{Cu}^{2+}-\mathrm{C}_{3} \mathrm{~N}_{4}$ nanoribbon complex in the presence of $\mathrm{Br}^{-}, \mathrm{C}_{6} \mathrm{H}_{5} \mathrm{O}_{7}^{3-}, \mathrm{Cl}^{-}, \mathrm{CN}^{-}, \mathrm{F}^{-}, \mathrm{H}_{2} \mathrm{PO}_{4}^{-}, \mathrm{HCO}_{3}^{-}, \mathrm{I}^{-}, \mathrm{NO}_{3}^{-}, \mathrm{OH}^{-}, \mathrm{SO}_{4}^{2-}, \mathrm{HCOO}^{-}$, $\mathrm{CH}_{3} \mathrm{COO}^{-}$, and $\mathrm{CH}_{3} \mathrm{CH}_{2} \mathrm{COO}^{-}(1 \mathrm{mM})$. (d) The value of fluorescent enhancement $\left(\mathrm{I} / \mathrm{I}_{0}\right)$ of the $\mathrm{Cu}^{2+}-\mathrm{C}_{3} \mathrm{~N}_{4}$ nanoribbon complex after the addition of $\mathrm{Br}^{-}, \mathrm{C}_{6} \mathrm{H}_{5} \mathrm{O}_{7}{ }^{3-}, \mathrm{Cl}^{-}, \mathrm{CN}^{-}, \mathrm{F}^{-}, \mathrm{H}_{2} \mathrm{PO}_{4}^{-}, \mathrm{HCO}_{3}^{-}$, $\mathrm{I}^{-}, \mathrm{NO}_{3}{ }^{-}, \mathrm{OH}^{-}$, and $\mathrm{SO}_{4}{ }^{2-}(1 \mathrm{mM}) . \mathrm{I}_{0}$ and I stand for the fluorescence intensities of $\mathrm{Cu}^{2+}-\mathrm{C}_{3} \mathrm{~N}_{4}$ nanoribbon complex at $415 \mathrm{~nm}$ in the absence and presence of different anions, respectively.

To investigate the selectivity of the $\mathrm{Cu}^{2+}-\mathrm{C}_{3} \mathrm{~N}_{4}$ nanoribbon-based probe towards $\mathrm{C}_{6} \mathrm{H}_{5} \mathrm{O}_{7}{ }^{3-}$, the fluorescence responses of the $\mathrm{Cu}^{2+}-\mathrm{C}_{3} \mathrm{~N}_{4}$ nanoribbon complex towards other anions $\left(\mathrm{Br}^{-}, \mathrm{Cl}^{-}\right.$, $\mathrm{CN}^{-}, \mathrm{F}^{-}, \mathrm{H}_{2} \mathrm{PO}_{4}^{-}, \mathrm{HCO}_{3}{ }^{-}, \mathrm{I}^{-}, \mathrm{NO}_{3}{ }^{-}, \mathrm{OH}^{-}$, and $\mathrm{SO}_{4}{ }^{2-}$ ) was measured. As shown in Figure $3 \mathrm{c}, \mathrm{d}$, most of the tested anions almost do not affect the PL intensity of the $\mathrm{Cu}^{2+}-\mathrm{C}_{3} \mathrm{~N}_{4}$ nanoribbon complex, while $\mathrm{C}_{6} \mathrm{H}_{5} \mathrm{O}_{7}{ }^{3-}$ can recover the fluorescence of $\mathrm{C}_{3} \mathrm{~N}_{4}$ nanoribbons effectively. Moreover, formic acid, sodium acetate, and propionic acid were also applied for the selectivity analysis of the proposed detection method (Figure S8), showing that the fluorescence presented the highest recovery in the presence of $\mathrm{C}_{6} \mathrm{H}_{5} \mathrm{O}_{7}{ }^{3-}$. Furthermore, the PL responses of the $\mathrm{Cu}^{2+}-\mathrm{C}_{3} \mathrm{~N}_{4}$ nanoribbon-based probe towards $\mathrm{C}_{6} \mathrm{H}_{5} \mathrm{O}_{7}{ }^{3-}$ were also investigated under different $\mathrm{pH}$ levels and metal ions environments. As shown in Figure $\mathrm{S} 9 \mathrm{a}$, the fluorescence intensity of the $\mathrm{Cu}^{2+}-\mathrm{C}_{3} \mathrm{~N}_{4}$ nanoribbon-based probe with or without $\mathrm{C}_{6} \mathrm{H}_{5} \mathrm{O}_{7}{ }^{3-}$ did not show obvious change in the $\mathrm{pH}$ range from 4 to 8 . More importantly, almost all of the cations $(10 \mu \mathrm{M})$ did not affect the fluorescence response of the $\mathrm{Cu}^{2+}-\mathrm{C}_{3} \mathrm{~N}_{4}$ nanoribbon-based probe, except for $\mathrm{Ag}^{+}$ (Figure S9b). Further, cell lysate $\left(1 \times 10^{6}\right.$ cell mL $\left.{ }^{-1}\right)$ and biological molecules $(10 \mu \mathrm{M})$, including glutamic acid, ascorbic acid, glutathione, and DNA, were introduced to examine the probe's stability. As Figure S9c shows, except for glutathione, the $\mathrm{Cu}^{2+}-\mathrm{C}_{3} \mathrm{~N}_{4}$ nanoribbon-base probe exhibited no obvious fluorescence 
change upon the addition of $\mathrm{C}_{6} \mathrm{H}_{5} \mathrm{O}_{7}{ }^{3-}$ and a biological molecule $(10 \mu \mathrm{M})$ mixture, even in cell lysate. These results indicate that the $\mathrm{Cu}^{2+}{ }_{-} \mathrm{C}_{3} \mathrm{~N}_{4}$ nanoribbon-based probe can be used for $\mathrm{C}_{6} \mathrm{H}_{5} \mathrm{O}_{7}{ }^{3-}$ detection in more complex environments.

The mechanism of the fluorescence quenching and recovering process were studied by DLS and zeta-potential for this system (Figure S10). The average hydrodynamic size of $\mathrm{C}_{3} \mathrm{~N}_{4}$ nanoribbons increased from 230 to $1523 \mathrm{~nm}$ in the presence of $\mathrm{Cu}^{2+}$ along with fluorescence quenching. A change of the zeta-potential from $-20.6 \mathrm{mV}$ to $-10.4 \mathrm{mV}$ was observed after the $\mathrm{C}_{3} \mathrm{~N}_{4}$ nanoribbons interacted with $\mathrm{Cu}^{2+}$. This result indicates that a non-fluorescent complex $\left(\mathrm{Cu}^{2+}-\mathrm{C}_{3} \mathrm{~N}_{4}\right.$ nanoribbon) was formed [50]. With the addition of $\mathrm{C}_{6} \mathrm{H}_{5} \mathrm{O}_{7}{ }^{3-}$, the hydrodynamic size decreased because of the chelation between $\mathrm{Cu}^{2+}$ and $\mathrm{C}_{6} \mathrm{H}_{5} \mathrm{O}_{7}{ }^{3-}$, indicating the release of $\mathrm{Cu}^{2+}$ from $\mathrm{C}_{3} \mathrm{~N}_{4}$ nanoribbons and resulting in the restoration of the fluorescence of $C_{3} N_{4}$ nanoribbons $[18,19,40]$. In order to rule out the effect of nonspecific binding, the PL intensity of the $\mathrm{C}_{3} \mathrm{~N}_{4}$ nanoribbons was monitored after the addition of different anion solutions. The result shows that, except for $\mathrm{OH}^{-}$, the other anions did not dramatically affect the PL intensity of the $\mathrm{C}_{3} \mathrm{~N}_{4}$ nanoribbons (Figure S11).

\subsection{Intracellular Imaging of $\mathrm{C}_{6} \mathrm{H}_{5} \mathrm{O}_{7}^{3-}$}

For further biological applications, the cytotoxicity of the $\mathrm{C}_{3} \mathrm{~N}_{4}$ nanoribbons and $\mathrm{Cu}^{2+}{ }_{-} \mathrm{C}_{3} \mathrm{~N}_{4}$ nanoribbon complex to HeLa cells was assessed through MTT assays. As shown in Figure S12, the viability of HeLa cells showed no obvious change after incubation with the $\mathrm{C}_{3} \mathrm{~N}_{4}$ nanoribbons or $\mathrm{Cu}^{2+}-\mathrm{C}_{3} \mathrm{~N}_{4}$ nanoribbon complex for $24 \mathrm{~h}$, indicating their good biocompatibility. Since the $\mathrm{Cu}^{2+}-\mathrm{C}_{3} \mathrm{~N}_{4}$ nanoribbon complex showed a highly selective and sensitive response towards $\mathrm{C}_{6} \mathrm{H}_{5} \mathrm{O}_{7}{ }^{3-}$, this novel fluorescent "off-on" probe based on $\mathrm{C}_{3} \mathrm{~N}_{4}$ nanoribbons might be potentially applied for the intracellular detection of $\mathrm{C}_{6} \mathrm{H}_{5} \mathrm{O}_{7}{ }^{3-}$. As shown in Figure 4, bright blue fluorescence was observed in $\mathrm{C}_{6} \mathrm{H}_{5} \mathrm{O}_{7}{ }^{3-}$-overloaded HeLa cells incubated with the $\mathrm{Cu}^{2+}-\mathrm{C}_{3} \mathrm{~N}_{4}$ nanoribbon complex, whereas no fluorescence was detected in the control HeLa cells incubated with the $\mathrm{Cu}^{2+}-\mathrm{C}_{3} \mathrm{~N}_{4}$ nanoribbon complex. Besides, Z-scan fluorescent images of living HeLa cells further confirmed that the $\mathrm{Cu}^{2+}-\mathrm{C}_{3} \mathrm{~N}_{4}$ nanoribbon-based probe can be taken up by the cells (Figure S9d). These results demonstrate that the $\mathrm{Cu}^{2+}-\mathrm{C}_{3} \mathrm{~N}_{4}$ nanoribbon complex is membrane permeable and could be used as a fluorescent visualizer for the intracellular imaging of $\mathrm{C}_{6} \mathrm{H}_{5} \mathrm{O}_{7}{ }^{3-}$.

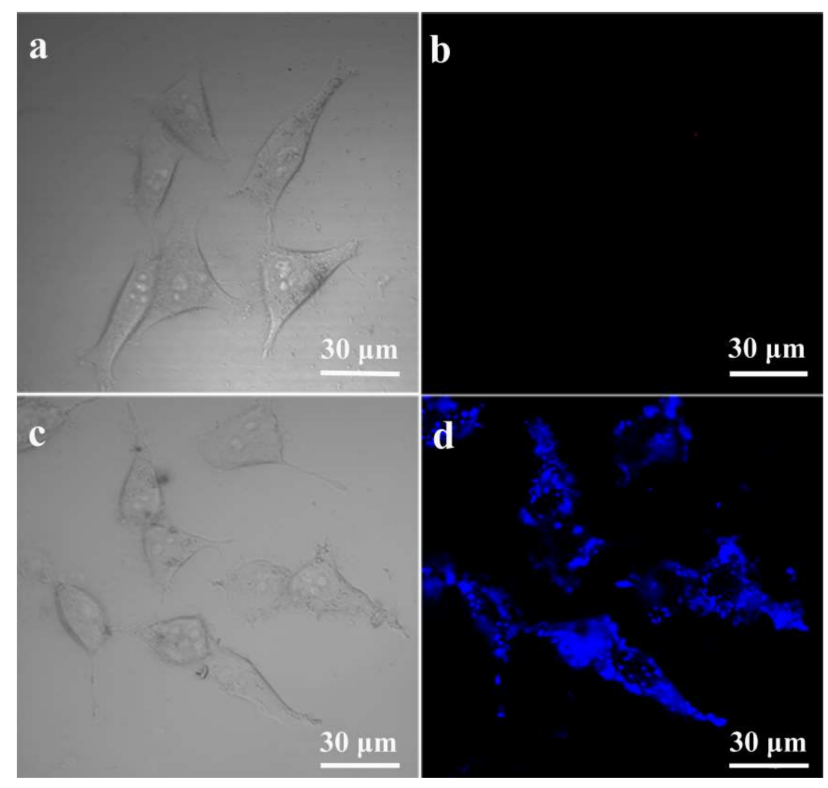

Figure 4. (a) Bright field and (b) fluorescent images of HeLa cells incubated with the $\mathrm{Cu}^{2+}-\mathrm{C}_{3} \mathrm{~N}_{4}$ nanoribbon complex for $4 \mathrm{~h}$. (c) Bright field and (d) fluorescent images of HeLa cells pretreated with $\mathrm{C}_{6} \mathrm{H}_{5} \mathrm{O}_{7} \mathrm{Na}_{3}(1 \mathrm{mM})$ for $12 \mathrm{~h}$ and then incubated with the $\mathrm{Cu}^{2+}-\mathrm{C}_{3} \mathrm{~N}_{4}$ nanoribbon complex for $4 \mathrm{~h}$. 


\section{Conclusions}

In summary, a novel fluorescent "off-on" probe based on $\mathrm{C}_{3} \mathrm{~N}_{4}$ nanoribbons was developed for $\mathrm{C}_{6} \mathrm{H}_{5} \mathrm{O}_{7}{ }^{3-}$ detection. The fluorescence of $\mathrm{C}_{3} \mathrm{~N}_{4}$ nanoribbons can be quenched by $\mathrm{Cu}^{2+}$ and then recovered by the addition of $\mathrm{C}_{6} \mathrm{H}_{5} \mathrm{O}_{7}{ }^{3-}$. The sensor using this fluorescent "off-on" probe showed a good detection linear range $(1 \sim 400 \mu \mathrm{M})$ with a low detection limit $(0.78 \mu \mathrm{M})$ as well as high selectivity in aqueous solutions. More importantly, this "off-on" probe based on $\mathrm{C}_{3} \mathrm{~N}_{4}$ nanoribbons exhibited good biocompatibility and low cytotoxicity in cell environments and can be utilized for intracellular imaging of $\mathrm{C}_{6} \mathrm{H}_{5} \mathrm{O}_{7}{ }^{3-}$.

Supplementary Materials: The following are available online at http:/ / www.mdpi.com/1424-8220/18/4/1163/ s1. Figure S1: (a) SEM image, (b) XPS survey spectrum, (c) XRD pattern and (d) FTIR spectrum of the bulk $\mathrm{C}_{3} \mathrm{~N}_{4}$. Figure S2: XPS survey spectrum of $C_{3} N_{4}$ nanoribbons. Figure S3: C 1s XPS spectrum of $C_{3} N_{4}$ nanoribbons. Figure S4: FTIR spectrum of $\mathrm{C}_{3} \mathrm{~N}_{4}$ nanoribbons. Figure S5: Effect of the $\mathrm{pH}$ value on the PL intensity of $\mathrm{C}_{3} \mathrm{~N}_{4}$ nanoribbons. Figure S6: The fluorescence responses of $\mathrm{C}_{3} \mathrm{~N}_{4}$ nanoribbons to various metal ions $\left(\mathrm{Cu}^{2+}, \mathrm{Al}^{3+}\right.$, $\mathrm{Ba}^{2+}, \mathrm{Co}^{2+}, \mathrm{Ag}^{+}, \mathrm{Fe}^{3+}, \mathrm{K}^{+}, \mathrm{Li}^{+}, \mathrm{Mg}^{2+}, \mathrm{Mn}^{2+}, \mathrm{Na}^{+}, \mathrm{Ni}^{2+}, \mathrm{Pb}^{2+}, \mathrm{Sn}^{2+}$, and $\left.\mathrm{Zn}^{2+}\right)$ at a concentration of $100 \mu \mathrm{M}$ in an aqueous solution. Figure S7: The fluorescent changes of $\mathrm{Cu}^{2+}-\mathrm{C}_{3} \mathrm{~N}_{4}$ nanoribbon complex as a function of interaction time after the addition of $\mathrm{C}_{6} \mathrm{H}_{5} \mathrm{O}_{7}{ }^{3-}(1 \mathrm{mM})$. Figure $\mathrm{S} 8$ : The value of the fluorescent enhancement $\left(\mathrm{I} / \mathrm{I}_{0}\right)$ of $\mathrm{Cu}^{2+}-\mathrm{C}_{3} \mathrm{~N}_{4}$ nanoribbon complex after the addition of $\mathrm{C}_{6} \mathrm{H}_{5} \mathrm{O}_{7}{ }^{3-}$, formic acid, sodium acetate, and propionic acid. $\mathrm{I}_{0}$ and I are the fluorescence intensities of the $\mathrm{Cu}^{2+}{ }_{-} \mathrm{C}_{3} \mathrm{~N}_{4}$ nanoribbon complex at $415 \mathrm{~nm}$ in the absence and presence of different anions, respectively. Figure S9: (a) Effect of the $\mathrm{pH}$ value on the fluorescence responses of the $\mathrm{Cu}^{2+}-\mathrm{C}_{3} \mathrm{~N}_{4}$ nanoribbon complex after the addition of $\mathrm{C}_{6} \mathrm{H}_{5} \mathrm{O}_{7}{ }^{3-}(1 \mathrm{mM})$. (b) Fluorescence responses of the $\mathrm{Cu}^{2+}-\mathrm{C}_{3} \mathrm{~N}_{4}$ nanoribbon complex upon the addition of $\mathrm{C}_{6} \mathrm{H}_{5} \mathrm{O}_{7}{ }^{3-}$ and metal ions $(10 \mu \mathrm{M})$ mixture. (c) Fluorescence responses of the $\mathrm{Cu}^{2+}-\mathrm{C}_{3} \mathrm{~N}_{4}$ nanoribbon complex upon the addition of $\mathrm{C}_{6} \mathrm{H}_{5} \mathrm{O}_{7}{ }^{3-}$ and biological molecule $(10 \mu \mathrm{M})$ mixture. (d) Z-scan images of living HeLa cells that were preincubated with $1 \mathrm{mM} \mathrm{C}_{6} \mathrm{H}_{5} \mathrm{O}_{7}{ }^{3-}$ for $12 \mathrm{~h}$ and then stained with the $\mathrm{Cu}^{2+}-\mathrm{C}_{3} \mathrm{~N}_{4}$ nanoribbon complex for $4 \mathrm{~h}$. Figure S10: (a) Hydrodynamic size of $\mathrm{C}_{3} \mathrm{~N}_{4}$ nanoribbons. (b) Hydrodynamic size of the $\mathrm{Cu}^{2+}{ }_{-} \mathrm{C}_{3} \mathrm{~N}_{4}$ nanoribbon complex. (c) Hydrodynamic size of $\mathrm{C}_{3} \mathrm{~N}_{4}$ nanoribbons after the $\mathrm{C}_{6} \mathrm{H}_{5} \mathrm{O}_{7}^{3-}$ was added into the $\mathrm{Cu}^{2+}-\mathrm{C}_{3} \mathrm{~N}_{4}$ nanoribbon solution. Figure S11: The fluorescence responses of $\mathrm{C}_{3} \mathrm{~N}_{4}$ nanoribbons in an aqueous solution upon the addition of different anions $\left(\mathrm{Br}^{-}, \mathrm{C}_{6} \mathrm{H}_{5} \mathrm{O}_{7}{ }^{3-}, \mathrm{Cl}^{-}, \mathrm{CN}^{-}, \mathrm{F}^{-}\right.$, $\mathrm{H}_{2} \mathrm{PO}_{4}^{-}, \mathrm{HCO}_{3}{ }^{-}, \mathrm{I}^{-}, \mathrm{NO}_{3}{ }^{-}, \mathrm{OH}^{-}, \mathrm{CH}_{3} \mathrm{COO}^{-}$, and $\mathrm{SO}_{4}{ }^{2-}$ ) (final concentration: $1 \mathrm{mM}$ ). Figure S12: Cell viability of HeLa cells incubated with various concentrations of $\mathrm{C}_{3} \mathrm{~N}_{4}$ nanoribbons (grey) or $\mathrm{Cu}^{2+}{ }_{-} \mathrm{C}_{3} \mathrm{~N}_{4}$ nanoribbon complex (black) for $24 \mathrm{~h}$. Table S1. Comparison of fluorescent citrate sensors.

Acknowledgments: This work was financially supported by the National Key Basic Research Program of China (2017YFA0205300), the National Natural Science Foundation of China (21475064), the Program for Changiiang Scholars and Innovative Research Team in University (IRT_15R37), and the Priority Academic Program Development of Jiangsu Higher Education Institutions (YX03002).

Author Contributions: Y.L.H. and D.L.Y. conceived and designed the experiments; C.Y., N.F., Z.W.S., and X.D.W. synthesized carbon nitride nanoribbons and performed the characterizations. Y.L.H. and D.L.Y. performed all the rest of the experiments; Y.L.H., D.L.Y., Z.M.L., and L.Z. analyzed the data; L.X.W. and L.H.W. contributed reagents/materials/analysis tools; Y.L.H. and D.L.Y. wrote the paper.

Conflicts of Interest: The authors declare no conflict of interest.

\section{References}

1. Wise, D.R.; Ward, P.S.; Shay, J.E.S.; Cross, J.R.; Gruber, J.J.; Sachdeva, U.M.; Platt, J.M.; DeMatteo, R.G.; Simon, M.C.; Thompson, C.B. Hypoxia promotes isocitrate dehydrogenase-dependent carboxylation of alpha-ketoglutarate to citrate to support cell growth and viability. Proc. Natl. Acad. Sci. USA 2011, 108, 19611-19616. [CrossRef] [PubMed]

2. Costello, L.C.; Franklin, R.B. Concepts of citrate production and secretion by prostate 1. Metab. Relatsh. Prostate 1991, 18, 25-46. [CrossRef]

3. Akram, M. Citric acid cycle and role of its intermediates in metabolism. Cell Biochem. Biophys. 2014, 68, 475-478. [CrossRef] [PubMed]

4. Ashbrook, M.J.; McDonough, K.L.; Pituch, J.J.; Christopherson, P.L.; Cornell, T.T.; Selewski, D.T.; Shanley, T.P.; Blatt, N.B. Citrate modulates lipopolysaccharide-induced monocyte inflammatory responses. Clin. Exp. Immunol. 2015, 180, 520-530. [CrossRef] [PubMed]

5. Hu, Y.Y.; Rawal, A.; Schmidt-Rohr, K. Strongly bound citrate stabilizes the apatite nanocrystals in bone. Proc. Natl. Acad. Sci. USA 2010, 107, 22425-22429. [CrossRef] [PubMed] 
6. Liu, Z.; Devaraj, S.; Yang, C.; Yen, Y. A new selective chromogenic and fluorogenic sensor for citrate ion. Sens. Actuators B 2012, 174, 555-562. [CrossRef]

7. Costello, L.; Franklin, R.; Narayan, P. Citrate in the diagnosis of prostate cancer. Prostate 1999, 38, $237-245$. [CrossRef]

8. Hikima, S.; Hasebe, K.; Taga, M. New amperometric biosensor for citrate with mercury film electrode. Electroanalysis 1992, 4, 801-803. [CrossRef]

9. Peres, R.G.; Moraes, E.P.; Micke, G.A.; Tonin, F.G.; Tavares, M.F.M.; Rodriguez-Amaya, D.B. Rapid method for the determination of organic acids in wine by capillary electrophoresis with indirect UV detection. Food Control 2009, 20, 548-552. [CrossRef]

10. Hasebe, K.; Hikama, S.; Yoshida, H. Determinations of citric acid by differential pulse polarography with immobilized enzymes. Fresenius J. Anal. Chem. 1990, 336, 232-234. [CrossRef]

11. Miyakoshi, K.; Komoda, M. Determination of citric acid and its decomposed products in edible oils by gas liquid chromatography. J. Am. Oil Chem. Soc. 1977, 54, 331-333. [CrossRef]

12. Kelebek, H.; Selli, S.; Canbas, A.; Cabaroglu, T. HPLC determination of organic acids, sugars, phenolic compositions and antioxidant capacity of orange juice and orange wine made from a turkish cv. Kozan. Microchem. J. 2009, 91, 187-192. [CrossRef]

13. Li, C.; Zhou, Y.; Li, Y.; Kong, X.; Zou, C.; Weng, C. Colorimetric and fluorescent chemosensor for citrate based on a rhodamine and $\mathrm{Pb}^{2+}$ complex in aqueous solution. Anal. Chim. Acta 2013, 774, 79-84. [CrossRef] [PubMed]

14. Zhuo, S.; Gong, J.; Zhang, P.; Zhu, C. High-throughput and rapid fluorescent visualization sensor of urinary citrate by CdTe quantum dots. Talanta 2015, 141, 21-25. [CrossRef] [PubMed]

15. Hang, Y.; Wang, J.; Jiang, T.; Lu, N.; Hua, J. Diketopyrrolopyrrole-based ratiometric/turn-on fluorescent chemosensors for citrate detection in the near-infrared region by an aggregation-induced emission mechanism. Anal. Chem. 2016, 88, 1696-1703. [CrossRef] [PubMed]

16. Yang, D.; Li, F.; Luo, Z.; Bao, B.; Hu, Y.; Weng, L.; Cheng, Y.; Wang, L. Conjugated polymer nanoparticles with aggregation induced emission characteristics for intracellular $\mathrm{Fe}^{3+}$ sensing. J. Polym. Sci. Part A: Polym. Chem. 2016, 54, 1686-1693. [CrossRef]

17. Ong, W.J.; Tan, L.L.; Ng, Y.H.; Yong, S.T.; Chai, S.P. Graphitic carbon nitride $\left(\mathrm{g}-\mathrm{C}_{3} \mathrm{~N}_{4}\right)$-based photocatalysts for artificial photosynthesis and environmental remediation: Are we a step closer to achieving sustainability? Chem. Rev. 2016, 116, 7159-7329. [CrossRef] [PubMed]

18. Dong, Y.; Wang, Q.; Wu, H.; Chen, Y.; Lu, C.H.; Chi, Y.; Yang, H.H. Graphitic carbon nitride materials: Sensing, imaging and therapy. Small 2016, 12, 5376-5393. [CrossRef] [PubMed]

19. Lee, E.Z.; Lee, S.U.; Heo, N.S.; Stucky, G.D.; Jun, Y.S.; Hong, W.H. A fluorescent sensor for selective detection of cyanide using mesoporous graphitic carbon(IV) nitride. Chem. Commun. 2012, 48, 3942-3944. [CrossRef] [PubMed]

20. Zhang, X.; Wang, H.; Wang, H.; Zhang, Q.; Xie, J.; Tian, Y.; Wang, J.; Xie, Y. Single-layered graphitic- $\mathrm{C}_{3} \mathrm{~N}_{4}$ quantum dots for two-photon fluorescence imaging of cellular nucleus. Adv. Mater. 2014, 26, 4438-4443. [CrossRef] [PubMed]

21. Li, Y.; Ouyang, S.; Xu, H.; Wang, X.; Bi, Y.; Zhang, Y.; Ye, J. Constructing solid-gas-interfacial fnton reaction over alkalinized- $\mathrm{C}_{3} \mathrm{~N}_{4}$ photocatalyst to achieve apparent quantum yield of $49 \%$ at $420 \mathrm{~nm}$. J. Am. Chem. Soc. 2016, 138, 13289-13297. [CrossRef] [PubMed]

22. Yang, Z.; Zhang, Y.; Schnepp, Z. Soft and hard templating of graphitic carbon nitride. J. Mater. Chem. A 2015, 3, 14081-14092. [CrossRef]

23. Huang, H.; Chen, R.; Ma, J.; Yan, L.; Zhao, Y.; Wang, Y.; Zhang, W.; Fan, J.; Chen, X. Graphitic carbon nitride solid nanofilms for selective and recyclable sensing of $\mathrm{Cu}^{2+}$ and $\mathrm{Ag}^{+}$in water and serum. Chem. Commun. 2014, 50, 15415-15418. [CrossRef] [PubMed]

24. Wang, A.; Wang, C.; Fu, L.; Wong-Ng, W.; Lan, Y. Recent advances of graphitic carbon nitride-based structures and applications in catalyst, sensing, imaging, and leds. Nano-Micro Lett. 2017, 9, 47. [CrossRef]

25. Zhang, S.; Li, J.; Zeng, M.; Xu, J.; Wang, X.; Hu, W. Polymer nanodots of graphitic carbon nitride as effective fluorescent probes for the detection of $\mathrm{Fe}^{3+}$ and $\mathrm{Cu}^{2+}$ ions. Nanoscale 2014, 6, 4157-4162. [CrossRef] [PubMed]

26. Zhang, X.L.; Zheng, C.; Guo, S.S.; Li, J.; Yang, H.H.; Chen, G. Turn-on fluorescence sensor for intracellular imaging of glutathione using $\mathrm{g}-\mathrm{C}_{3} \mathrm{~N}_{4}$ nanosheet $-\mathrm{MnO}_{2}$ sandwich nanocomposite. Anal. Chem. 2014, 86, 3426-3434. [CrossRef] [PubMed] 
27. Tian, J.; Liu, Q.; Asiri, A.M.; Sun, X.; He, Y. Ultrathin graphitic $\mathrm{C}_{3} \mathrm{~N}_{4}$ nanofibers: Hydrolysis-driven top-down rapid synthesis and application as a novel fluorosensor for rapid, sensitive, and selective detection of $\mathrm{Fe}^{3+}$. Sens. Actuators B 2015, 216, 453-460. [CrossRef]

28. Lee, E.Z.; Jun, Y.S.; Hong, W.H.; Thomas, A.; Jin, M.M. Cubic mesoporous graphitic carbon(IV) nitride: An all-in-one chemosensor for selective optical sensing of metal ions. Angew. Chem. Int. Ed. 2010, 49, 9706-9710. [CrossRef] [PubMed]

29. Tian, J.; Liu, Q.; Asiri, A.M.; Al-Youbi, A.O.; Sun, X. Ultrathin graphitic carbon nitride nanosheet: A highly efficient fluorosensor for rapid, ultrasensitive detection of $\mathrm{Cu}^{2+}$. Anal. Chem. 2013, 85, 5595-5599. [CrossRef] [PubMed]

30. Field, T.B.; McCourt, J.L.; McBryde, W. Composition and stability of iron and copper citrate complexes in aqueous solution. Can. J. Chem. 1974, 52, 3119-3124. [CrossRef]

31. Still, E.R.; Wikberg, P. Solution studies of systems with polynuclear complex formation. 1. The copper(II) citrate system. Inorg. Chim. Acta 1980, 46, 147-152. [CrossRef]

32. Parry, R.; Dubois, F. Citrate complexes of copper in acid solutions. J. Am. Chem. Soc. 1952, 74, 3749-3753. [CrossRef]

33. Zhang, Y.; Pan, Q.; Chai, G.; Liang, M.; Dong, G.; Zhang, Q.; Qiu, J. Synthesis and luminescence mechanism of multicolor-emitting g- $\mathrm{C}_{3} \mathrm{~N}_{4}$ nanopowders by low temperature thermal condensation of melamine. Sci. Rep. 2013, 3, 1943. [CrossRef] [PubMed]

34. Zhang, X.; Xie, X.; Wang, H.; Zhang, J.; Pan, B.; Xie, Y. Enhanced photoresponsive ultrathin graphitic-phase $\mathrm{C}_{3} \mathrm{~N}_{4}$ nanosheets for bioimaging. J. Am. Chem. Soc. 2013, 135, 18-21. [CrossRef] [PubMed]

35. Yang, J.; Wu, X.; Li, X.; Liu, Y.; Gao, M.; Liu, X.; Kong, L.; Yang, S. Synthesis and characterization of nitrogen-rich carbon nitride nanobelts by pyrolysis of melamine. Appl. Phys. A Mater. Sci. Process. 2011, 105, 161-166. [CrossRef]

36. Rong, M.; Song, X.; Zhao, T.; Yao, Q.; Wang, Y.; Chen, X. Synthesis of highly fluorescent P,O-g- $\mathrm{C}_{3} \mathrm{~N}_{4}$ nanodots for the label-free detection of $\mathrm{Cu}^{2+}$ and acetylcholinesterase activity. J. Mater. Chem. C 2015, 3, 10916-10924. [CrossRef]

37. Bai, X.; Cao, C.; Xu, X.; Yu, Q. Synthesis and characterization of crystalline carbon nitride nanowires. Solid State Commun. 2010, 150, 2148-2153. [CrossRef]

38. Dementjev, A.P.; de Graaf, A.; van de Sanden, M.C.M.; Maslakov, K.I.; Naumkin, A.V.; Serov, A.A. X-ray photoelectron spectroscopy reference data for identification of the $\mathrm{C}_{3} \mathrm{~N}_{4}$ phase in carbon-nitrogen films. Diam. Relat. Mater. 2000, 9, 1904-1907. [CrossRef]

39. Lu, X.; Gai, L.; Cui, D.; Wang, Q.; Zhao, X.; Tao, X. Synthesis and characterization of $\mathrm{C}_{3} \mathrm{~N}_{4}$ nanowires and pseudocubic $\mathrm{C}_{3} \mathrm{~N}_{4}$ polycrystalline nanoparticles. Mater. Lett. 2007, 61, 4255-4258. [CrossRef]

40. Tang, Y.; Song, H.; Su, Y.; Lv, Y. Turn-on persistent luminescence probe based on graphitic carbon nitride for imaging detection of biothiols in biological fluids. Anal. Chem. 2013, 85, 11876-11884. [CrossRef] [PubMed]

41. Gunasekaran, S.; Sailatha, E.; Seshadri, S.; Kumaresan, S. FTIR, FT raman spectra and molecular structural confirmation of isoniazid. Indian J. Pure Appl. Phys. 2009, 47, 12-18.

42. Gunasekaran, S.; Seshadri, S.; Muthu, S. Vibrational spectra and normal coordinate analysis of flucytosine. Indian J. Pure Appl. Phys. 2006, 44, 581-586.

43. Urbaniak-Domagala, $\mathrm{W}$. The use of the spectrometric technique FTIR-ATR to examine the polymers surface. In Advances Aspects Spectroscopy; Farrukh, M.A., Ed.; InTech: London, UK, 2012; pp. 85-104, ISBN 978-953-51-0715-6.

44. Lin, T.; Zhong, L.; Wang, J.; Guo, L.; Wu, H.; Guo, Q.; Fu, F.; Chen, G. Graphite-like carbon nitrides as peroxidase mimetics and their applications to glucose detection. Biosens. Bioelectron. 2014, 59, 89-93. [CrossRef] [PubMed]

45. Barman, S.; Sadhukhan, M. Facile bulk production of highly blue fluorescent graphitic carbon nitride quantum dots and their application as highly selective and sensitive sensors for the detection of mercuric and iodide ions in aqueous media. J. Mater. Chem. 2012, 22, 21832-21837. [CrossRef]

46. Yang, D.; Dai, C.; Hu, Y.; Liu, S.; Weng, L.; Luo, Z.; Cheng, Y.; Wang, L. A new polymer-based fluorescent chemosensor incorporating propane-1,3-dione and 2,5-diethynylbenzene moieties for detection of copper(II) and iron(III). Polymers 2017, 9, 267. [CrossRef] 
47. Hu, Y.; Huang, Y.; Tan, C.; Zhang, X.; Lu, Q.; Sindoro, M.; Huang, X.; Huang, W.; Wang, L.; Zhang, H. Two-dimensional transition metal dichalcogenide nanomaterials for biosensing applications. Mater. Chem. Front. 2016, 1, 24-36. [CrossRef]

48. Rajalakshmi, K.; Nam, Y.S.; Selvaraj, M.; Lee, Y.; Lee, K.B. Metal free bioimaging reagent for intracellular citrate in prostate cancer cells using aryl boronate derivative. Sens. Actuators B 2018, 259, 90-96. [CrossRef]

49. Parker, D.; Yu, J. A pH-insensitive, ratiometric chemosensor for citrate using europium luminescence. Chem. Commun. 2005, 25, 3141-3143. [CrossRef] [PubMed]

50. Zhang, Q.; Song, C.; Zhao, T.; Fu, H.W.; Wang, H.Z.; Wang, Y.J.; Kong, D.M. Photoluminescent sensing for acidic amino acids based on the disruption of graphene quantum dots/europium ions aggregates. Biosens. Bioelectron. 2015, 65, 204-210. [CrossRef] [PubMed]

(C) 2018 by the authors. Licensee MDPI, Basel, Switzerland. This article is an open access article distributed under the terms and conditions of the Creative Commons Attribution (CC BY) license (http:/ / creativecommons.org/licenses/by/4.0/). 